\title{
Childhood Acute Monoblastic and Monocytic Leukemia
}

National Cancer Institute

\section{Source}

National Cancer Institute. Childhood Acute Monoblastic and Monocytic Leukemia. NCI

Thesaurus. Code C7940.

An acute monoblastic and monocytic leukemia occurring in children. 